\title{
The Effect of Abomasal Infusion of Various Levels of Dietary Casein on the Utilization of Dietary Nitrogen and Carbohydrates in Goats
}

\author{
Tsutomu Fujihara and Iwao Tasaki*
}

Faculty of Agriculture, Shimane University, Matsue-shi 690 *Faculty of Agriculture, Nagoya University, Nagoya-shi 464

(Received November 13, 1978)

\begin{abstract}
An experiment was carried out, using goats sustained by abomasal feeding, to investigate the effect of dietary casein level on the utilization of dietary nitrogen and carbohydrates as well as on the changes of some blood constituents. The results obtained were discussed in comparison with those reported by other workers on monogastric animals. 1) Apparent digestibility of protein tended to increase with an increase of dietary casein level from $10 \%$ to $20 \%$, but the true digestibility of protein was not changed by the dietary casein level. The result was similar to that obtained by other workers us ing pigs or rats. A significant increase in nitrogen retention was observed when dietary casein level was increased from $10 \%$ to $20 \%$. 2) The biological value of casein was not changed by the dietary casein level $(10 \sim 20 \%)$, and the average value was $57 \%$. This figure was almost the same as that of rats. 3) The concentration of blood urea-nitrogen significantly increased with an increase of dietary casein level, and was proportional to the nitrogen retention. This result shows that the blood urea serves as reserved nitrogen which is of nutritional significance with regards to blood urea in the nitrogen metabolism of ruminants. 4) The concentration of plasma total protein was not changed by an increase of dietary casein level, and was within the range generally accepted in mammals. 5) The digestibility of starch tended to increase with an increase of dietary casein level, though there was no significant difference. The abomasally-infused glucose was almost completely absorbed from the intestinal lumen, and this shows that the absorption of glucose in the post-ruminal alimentary tract of goats may be similar to that of mono-gastric animals.

Jap. J. Zootech. Sci., 50 (7): 471-478, 1979
\end{abstract}

FuJIHARA and TASAKI ${ }^{1)}$ found that when the purified diet containing $13 \%$ casein was introduced into the abomasum of goats, the protein digestibility was almost the same as that of the diet introduced ruminally, and that the nitrogen retention was also almost the same in both treatments.

It has been established in nitrogen balance studies that the utilization of protein is affected by its dietary level. HENRY and $\mathrm{KON}^{2)}$ reported that a higher biological value was observed for casein with adult rats at $4 \%$ than at $8 \%$ level of protein intake, and that a significantly higher biological value was obtained at $8 \%$ than at $16 \%$ level of dietary protein. 
In the present experiment, the effect of dietary casein level on nitrogen retention, blood urea-nitrogen concentration and plasma total protein in goats sustained by abomasal feeding alone, was investigated.

\section{Experimental Procedure}

Three castrated male Japanese Saanen goats, each weighing $24 \sim 28 \mathrm{~kg}$, were used. Each goat was fitted with permanent fistulas in both rumen and abomasum by the method described by UKaI et al. ${ }^{3)}$ The composition of the diets used in the present experiment is shown in Table 1. Casein was used as a sole source of dietary protein at 10,15 and 20 percent levels. The feeding procedure was almost similar to that of

Table 1. Composition of experimental diets.

\begin{tabular}{lrrr}
\hline \multirow{2}{*}{ Ingredients } & \multicolumn{3}{c}{ Dietary casein level (\%) } \\
\cline { 2 - 4 } & 10 & 15 & 20 \\
\hline Casein* & 10.00 & 15.00 & 20.00 \\
Cornstarch & 45.00 & 40.00 & 35.00 \\
Glucose & 30.00 & 30.00 & 30.00 \\
Cellulose** & 5.00 & 5.00 & 5.00 \\
Corn oil & 1.00 & 1.00 & 1.00 \\
Aluminum silicate & 3.78 & 3.78 & 3.78 \\
Vitamin mixture*** & 0.12 & 0.12 & 0.12 \\
Mineral mixture*** & 5.00 & 5.00 & 5.00 \\
Choline chloride & 0.10 & 0.10 & 0.10 \\
\hline
\end{tabular}

* Contained $13.8 \%$ nitrogen. ** Powder of filter paper for feed (200 mesh), TOYO Chemical Industry, Tokyo, Japan. *** Referred from Matrone et $a l .{ }^{35,36)}$.

the experiment described by FuJIHARA et al. ") A seven-day preliminary period preceded the 6-day sampling period. Prior to the preliminary feeding, the animals were gradually acclimatized to the experimental diet for 7 to 10 days. One-half of the daily ration was suspended in warm water $\left(40^{\circ} \mathrm{C}, 300 \mathrm{ml}\right)$ and infused into the abomasum at 9:00 hour, and another one-half at 17:30 hour. The infusion rate was regulated at 150 $\mathrm{m} l$ an hour by a speed-controlled injector. Feces and urine were collected just before the morning feeding. Feces were dried for 48 hours in a forced-air drier at $65^{\circ} \mathrm{C}$. A few drops of $10 \% \mathrm{H}_{2} \mathrm{SO}_{4}$ was added to the bottle used for the collection of urine as a reagent preventing the loss of nitrogen. Nitrogen in the diet, feces and urine were analyzed by the Kjeldahl method, and total sugar in the diet and feces by AOAC meth$\mathrm{od}^{5)}$. On the final day of each trials, $5 \mathrm{ml}$ of jugular blood was collected at 9:00, 11: $00,13: 00,15: 00$ and 17:00 hour, to determine glucose, urea nitrogen and plasma total protein. Blood glucose, blood urea-nitrogen and plasma total protein were analyzed using the Unitest System (Model 300, Biodynamics, Inc., USA). About $50 \mathrm{ml}$ of rumen contents were sampled through the rumen fistula just before the blood sampling on 
the final day of each trial, and ammonia concentration of the rumen fluid was measured by the method of HAwK et al." .

\section{Results and Discussion}

Table 2 shows the apparent digestibility of organic matter, crude protein, starch and glucose, and the nitrogen balance of goats fed the diets containing 10, 15 and 20 percent casein. The digestibility of organic matter significantly $(\mathrm{P}<0.05)$ increased with an increase of dietary casein level. Apparent digestibility of crude protein tended to increase with an increase of casein level in the diet, and this tendency was in

Table 2. Apparent digestibility and nitrogen balance.

\begin{tabular}{lccc}
\hline & \multicolumn{3}{c}{ Dietary casein level (\%) } \\
\cline { 2 - 4 } & 10 & 15 & 20 \\
\hline Apparent digestibility (\%) & & \\
Organic matter & $71.7 \pm 1.6^{* a}$ & $75.9 \pm 3.4^{\mathrm{b}}$ & $82.3 \pm 1.5^{\mathrm{c}}$ \\
Crude protein & $72.0 \pm 3.6$ & $78.4 \pm 1.7$ & $82.2 \pm 0.4$ \\
& $(98.4 \pm 3.1)^{* *}$ & $(97.3 \pm 0.9)$ & $(95.9 \pm 0.5)$ \\
Starch & $77.5 \pm 0.9$ & $79.3 \pm 4.4$ & $89.3 \pm 2.3$ \\
Glucose & $98.8 \pm 0.3$ & $99.6 \pm 0.1$ & $99.9 \pm 0.1$ \\
Nitrogen balance & $(\mathrm{g} / \mathrm{day})$ & & \\
Intake & $6.6 \pm 0.2$ & $9.3 \pm 0.6$ & $12.7 \pm 0.4$ \\
Excretion & $1.8 \pm 0.2$ & $2.0 \pm 0.1$ & $2.3 \pm 0.1$ \\
Fecal & $4.6 \pm 0.6^{\mathrm{a}}$ & $5.3 \pm 1.0^{\mathrm{ab}}$ & $7.3 \pm 0.7^{\mathrm{b}}$ \\
$\quad$ Urinary & $0.2 \pm 0.3^{\mathrm{a}}$ & $2.0 \pm 0.5^{\mathrm{b}}$ & $3.1 \pm 0.4^{\mathrm{c}}$ \\
Retention & $(4.1 \pm 5.8)^{* *}$ & $(28.4 \pm 7.4)$ & $(30.8 \pm 4.2)$ \\
\hline
\end{tabular}

* Mean \pm S. E. of three goats. ** Values in parentheses are true digestibility of protein based on the fecal nitrogen after the feeding of protein free diet. **:* Values in parentheses are percent of digested nitrogen. a $\sim \mathrm{c}$ : Means within columns with different superscripts are significantly different $(P<0.05)$.

agreement with observed by PRESTON et al. ${ }^{7}$. The true digestibility of protein was not changed by the change of dietary casein level. The digestibility of starch tended to increase slightly with an increase of dietary casein level, though no significant difference was observed. The digestibilities of protein and starch in the present experiment were closely in agreement with the results obtained by FujIHARA et al. ${ }^{4}$, in which diet containing 15\% of casein was introduced into the abomasum. Fecal nitrogen output slightly increased in the feeding of the $20 \%$ casein diet. The urinary nitrogen excretion increased with an increase of dietary casein level. When the $10 \%$ casein diet was given, the nitrogen retention was $0.2 \mathrm{~g}$ per day, which was equivalent to $4.1 \%$ of the digested nitrogen. The nitrogen retention increased to $2.0 \mathrm{~g}$ and $3.1 \mathrm{~g}$ per day in the feeding of the $15 \%$ and $20 \%$ casein diets, and these figures were proportionate to $28 \%$ and $31 \%$ of digested nitrogen, respectively. There was a significant increase in nitrogen retention with an increase of dietary casein level $(\mathbf{P}<0.05)$. 
The retained nitrogen after feeding the 15\% casein diet was in accordance with the result obtained by FuJIHARA et al. ${ }^{4}$. The utilization coefficient of casein after feeding the $20 \%$ casein diet was very comparable to that of urea $(14.1 \mathrm{~g} \mathrm{~N} /$ day) which was infused into the abomasum of goats fed a low-protein ration as described by Fujihara and TASAKI ${ }^{8}$.

The major objective of the present experiment was to compare the utilization of dietary nutrients in the post-ruminal alimentary tract of goats with that in mono-gastric animals. TEague and Hanson ${ }^{9)}$ reported that the digestibility of crude protein was 93 96\% in pigs fed a purified diet containing $15 \%$ casein. HENRY and $\mathrm{KON}^{2)}$ also reported that the true digestibility of casein in young rats was $99.3 \%$ when a diet containing $12 \sim 16 \%$ protein was given. As shown in Table 3 , the biological value of casein for goats was $56.1,61.4$ and $54.8 \%$ after feeding the 10,15 and $20 \%$ casein

Table 3. Biological value of protein in goats fed 10,15 and $20 \%$ dietary casein.

\begin{tabular}{cccc}
\hline $\begin{array}{c}\text { Dietary } \\
\text { casein } \\
\text { level } \\
(\%)\end{array}$ & $\begin{array}{c}\text { Fecal } \\
\text { nitrogen } \\
(\mathrm{g} / \text { day })\end{array}$ & $\begin{array}{c}\text { Urinary } \\
\text { nitrogen } \\
(\mathrm{g} / \text { day })\end{array}$ & $\begin{array}{c}\text { Biological } \\
\text { value } \\
(\%)\end{array}$ \\
\hline 0 & $1.74 \pm 0.21^{*}$ & $1.73 \pm 0.17$ & - \\
10 & $1.84 \pm 0.20$ & $4.60 \pm 0.62$ & $56.1 \pm 7.5$ \\
15 & $1.99 \pm 0.08$ & $5.33 \pm 1.00$ & $61.4 \pm 7.9$ \\
20 & $2.27 \pm 0.08$ & $7.26 \pm 0.67$ & $54.8 \pm 4.2$ \\
Average & - & - & $57.4 \pm 2.0$ \\
\hline
\end{tabular}

* Mean $\pm S$. E. of three goats.

diets, respectively. There was no significant effect of dietary casein level on the biological value of casein. HENRY and $\mathrm{KON}^{2)}$ reported that in young rats, the biological value of casein at a $16 \%$ level of protein intake was $47 \sim 64 \%$, and in adult rats, the biological value of casein was $60.5 \%$ at an $8 \%$ level of protein intake. The result obtained in the present experiment $(57.4 \%)$ was almost similar to that for rats reported by HENRY and $\mathrm{K}^{2}{ }^{2}$. This suggests that goats are capable of utilizing casein in the post-ruminal alimentary tract when their diets are introduced into the abomasum, in the same way as mono-gastric animals do.

As indicated in Table 2, the digestibility of starch in the present experiment tended to increase with an increase of dietary casein level, though no significant difference was observed. This may be due to the decrease of starch content in the diet. According to our previous studies ${ }^{2,4}$, when a high starch diet $(75 \sim 80 \%)$ was introduced into the abomasum of goats, the digestibility of starch was $32 \sim 65 \%$, whereas, when $45 \%$ starch diet was introduced into the abomasum, the digestibility of starch increașed to $73 \%$. LARSEN et al. ${ }^{10)}$ also observed a low digestibility of starch when a large amount of cornstarch was introduced into the abomasum of steers. On the other hand, high digestibility of starch in mono-gastric animals has been reported. YosHIDA 
Table 4. Concentrations of blood glucose, blood urea-nitrogen, plasma total protein and ruminal ammonia in goats fed 10,15 and $20 \%$ dietary casein.

\begin{tabular}{|c|c|c|c|}
\hline & \multicolumn{3}{|c|}{ Dietary casein level $(\%)$} \\
\hline & 10 & 15 & 20 \\
\hline \multicolumn{4}{|c|}{ Blood glucose $(\mathrm{mg} / 100 \mathrm{ml})$} \\
\hline $0 *$ & $46.3 \pm 3.8 * *$ & $43.0 \pm 1.2$ & $42.3 \pm 2.0$ \\
\hline 2 & $60.7 \pm 4.7$ & $58.3 \pm 1.2$ & $69.0 \pm 3.2$ \\
\hline 4 & $62.7 \pm 3.5$ & $59.7 \pm 3.0$ & $59.0 \pm 9.5$ \\
\hline 6 & $60.7 \pm 5.2$ & $61.0 \pm 4.5$ & $59.0 \pm 5.0$ \\
\hline 8 & $60.3 \pm 10.8$ & $62.0 \pm 6.5$ & $54.0 \pm 3.2$ \\
\hline Average & $58.1 \pm 3.0$ & $56.7 \pm 4.3$ & $56.7 \pm 4.3$ \\
\hline \multicolumn{4}{|c|}{ Blood urea-nitrogen $(\mathrm{mg} / 100 \mathrm{~m} l)$} \\
\hline & $8.3 \pm 0.5^{\mathrm{a}}$ & $14.2 \pm 1.9^{b}$ & $14.8 \pm 0.8^{b}$ \\
\hline \multicolumn{4}{|c|}{ Plasma total protein $(\mathrm{g} / 100 \mathrm{~m} l)$} \\
\hline & $7.2 \pm 0.1$ & $7.3 \pm 0.2$ & $7.2 \pm 0.1$ \\
\hline \multicolumn{4}{|c|}{ Ruminal ammonia $(\mathrm{mg} / 100 \mathrm{~m} l)$} \\
\hline & $11.5 \pm 0.5^{\mathrm{a}}$ & $15.3 \pm 1.3^{b}$ & $18.4 \pm 0.7^{\mathfrak{c}}$ \\
\hline
\end{tabular}

* Hours after feeding. ** Mean \pm S.E. of three goats. a $\sim c$ : Means within columns witn different superscripts are significantly different $(\mathrm{P}<0.05)$.

and MoRIMOTo ${ }^{11)}$ reported that $99 \%$ of starch was digested by rats fed a diet containing 57\% cornstarch. Teague and HANSON $^{9)}$ also reported that starch digestibility was $91 \sim 100 \%$ in pigs fed a purified diet containing $70 \%$ cornstarch. It is probable from these results that there is a certain limit in starch digestion in the post-ruminal alimentary tract of goats when a large amount of starch was directly introduced into the abomasum.

As shown in Table 2, the abomasally-infused glucose was almost completely absorbed from the intestinal lumen in the same manner as the result described by FuJIHARA et al. ${ }^{4}$, and this is quite in agreement with the result of CunNINGHAM ${ }^{12)}$ using young pigs. This shows that the absorption of glucose in the post-ruminal alimentary tract of goats may be similar to that of mono-gastric animals. As shown in Table 4, the blood glucose level was not changed by an increase of dietary level of casein, and was very comparable to that of FuJiHaRa et al. ${ }^{4)}$ According to Cunningham ${ }^{12}$, the blood glucose level was extremely increased by the glucose feeding using a stomach tube in young pigs. In the present experiment, however, the increment of blood glucose level was smaller and the blood glucose level was remarkably lower than those of pigs $^{12)}$. From these results, it is assumed that the response of absorbed glucose to the blood glucose level in goats was slower than that in mono-gastric animals.

The concentration of blood urea-nitrogen after feeding 15 and $20 \%$ casein diets was significantly $(\mathrm{P}<0.05)$ higher than that after feeding $10 \%$ casein diet (Table 4 ), and the concentration was proportional to the nitrogen retention as indicated in Table 2. In ruminants, it has been shown that the quality of absorbed nitrogenous compounds is reffected in the level of circulating blood urea-nitrogen ${ }^{13)}$. According to 
PRESTON et al. ${ }^{7}$, the blood urea-nitrogen in lambs was altered by feeding various sources of carbohydrates and protein. Puchal et al. ${ }^{14}$ )also reported that the quality of protein fed to young pigs was reflected in the blood urea-nitrogen level, and that the plasma urea levels appeared to be invesely proportional to the body weight gain and feed efficiency. This was to be expected on the basis of the amino acids from unbalanced protein being catabolized and excreted via urea. In the present study, casein was used as the sole source of dietary protein, hence, the increase of blood urea-nitrogen after feeding 15 and $20 \%$ casein diets could be explained by the suggestion of Puchal et al. ${ }^{14}$ in which the quality of dietary protein was reflected in the blood urea-nitrogen level.

In wethers given a ration with varying levels of soybean meal ad libitum, PresTON et al. ${ }^{15)}$ found that the blood nitrogen constituents could be quantitated with protein intake. MCINTYRE ${ }^{16)}$ also reported that the plasma urea-nitrogen of sheep increased linearly to about $30 \mathrm{mg} / 100 \mathrm{ml}$ with increasing amounts of dietary nitrogen $(6.8$ to $46.3 \mathrm{~g} /$ day). In the present experiment, the concentration of blood urea-nitrogen significantly increased with an increased of nitrogen intake from $6.6 \mathrm{~g}(10 \% \mathrm{ca}$ sein diet) to $9.3 \mathrm{~g}$ ( $15 \%$ casein diet), but the level was not changed when the nitrogen intake was increased to $12.7 \mathrm{~g}$ ( $20 \%$ casein diet). The level of blood urea-nitrogen in this study was somewhat lower than that of PRESTON et al. ${ }^{15)}$ and that of MCINTYRE ${ }^{16)}$, and was very comparable with that of POTTER and BERGEN ${ }^{17}$ in which the sheep was orally fed $400 \sim 600 \mathrm{~g} /$ day of a maintenance ration and duodenally administered $50 \sim$ $150 \mathrm{~g} /$ day of casein-whole egg powder mixture $(2: 3 \mathrm{~W} / \mathrm{W})$. Likewise, the blood urea level in this experiment was very much in agreement with that of PuCHAL et al. ${ }^{14}$ using pigs fed a diet containing 20\% dried skim milk. From the results mentioned above, it is suggested that when the goats were abomasally infused the diet, the response of blood urea-nitrogen level to nitrogen intake is similar to that of mono-gastric animals rather than that of ruminants fed the diet ruminally.

It has been substantiated that when excessive amounts of dietary protein were consumed, and if the absorbed amino acids can not be used for protein synthesis, the free amino acids in the blood plasma are degraded with a concomitant increase in plasma urea levels and urinary nitrogen excretion ${ }^{18.18)}$. In ruminants, however, the blood urea-nitrogen is available in nitrogen metabolism as a recycled nitrogen source, especially when animals were given a low nitrogen ration ${ }^{20}$. As indicated in Table 2, the retained nitrogen significantly increased with an increase of dietary casein level, although urinary nitrogen excretion increased. This result shows that the increase of retained nitrogen may be reflected in an increase of blood urea-nitrogen which serves as reserved nitrogen, and this confirms the nutritional significance of blood ureanitrogen in the nitrogen metabolism of ruminants ${ }^{21,22)}$. This phenomenon could be illustrated by the significant increase of ruminal ammonia concentration with an increase of dietary casein level (Table 4), even though the goats were given no feed ruminally.

As indicated in Table 4, the plasma protein level was not affected by an increase 
of dietary casein level, and these values were almost similar to that generally accepted in mammals ${ }^{29}$. MunRo $^{24)}$ described that the plasma protein may represent a vehicle of limited capacity for amino acid transport between the liver and other tissues. The relationship between plasma protein and plasma amino acid in goats should be studied in detail.

\section{Acknowledgement}

The present work was supported by a grant-in-aid (No. 176170) for scientific research from the Ministry of Education, Science and Culture in Japan.

\section{References}

1) Fujihara, T. and I. Tasakr, Jap. J. Zootech. Sci., 44: 125-127. 1973.

2) Henry, K. M. and S. K. Kon, Brit. J. Nutr., 11: 305-313. 1957.

3) Ukai, A., T. Fujihara, F. Shibata and I. Tasaki, Jap. J. Zootech. Sci., 44: 625-627. 1973

4) Fujihara, T., T. Furuhashi and I. Tasaki, Jap. J. Zootech. Sci., (50: 479 487) 1979.

5) Hortz, H. (ed.) Official Method of Analysis, 9th ed. 288-289. A. O. A.C. Washington, D. C. 1960.

6) Hawk, P.B; B.L. Oser and W.H. Summerson, Practical physiological Chemistry. 889 McGraw-Hill Co. New York. 1954.

7) Preston, R. L., D. D. Schnakenberg and W. H. Pfander, J. Nutr., 86: 281-288. 1965.

8) Fujihara, T. and I. Tasakr, J. Agr. Sci. Camb., 85: 185-187. 1975.

9) Teague, H.S. and L. E. Hanson, J. Anim. Sci, 13: 206-214. 1954.

10) Larsen, H. J., G. E. Stoddard, N. L. Jacobson and R. S. Allen, J. Anim. Sci., 15: 473-484. 1956.

11) Yoshida, M. and H. Morimoto, J. Nutr., 57: 565-577. 1955.

12) Cunningham, H. M., J. Anim. Sci., 18: 964-975. 1959.

13) Lewis, D., J. Agr. Sci. Camb., 48: 438-446. 1957.

14) Puchal, F., V.W. Hays, V.C. Speer, J.D. Jones and D. V. Carton, J. Nutr., 76: 11-16. 1962.

15) Preston, R. L., L. H. Bruer and W. H. Pfander, J. Anim. Sci., 20: 947 (Abstract). 1961.

16) McIntyre, K. H., Aust. J. Agr. Res., 21: 501-507. 1970.

17) Putter, E. L. and W.G. Bergen, J. Anim. Sci., 39: 775-779. 1974.

18) Harper, A.E., Can. J. Biochem., 43: 1589-1593. 1965.

19) Harper, A.E., Am. J. Clin. Nutr., 21: 358-361. 1968.

20) Schmidt-Nirlsen, B., K. Schmidt-Nielsen, T. R. Houpt and S. A. Jarnum, Am. J. Physiol., 188: $477-484.1957$.

21) Mcintyre, K. H., Aust. J. Agr. Res., 22: 429-441. 1971.

22) Vercoe, J.E., Aust. J. Agr. Res., 20: 191-197. 1969.

23) HaRPer, H. A., Review of Physiological Chemistry. 15th ed. 199. Maruzen Co. Ltd., Tokyo. 1975.

24) Munro, H. N., Mammarian Protein Metabolism. Vol. IV. 523-556. Academic Press. New York. 1970.

25) Matrone, G., H. A. Ramsay and G. H. Wise, Proc. Soc, Expt. Biol. Med., 95: 731-734. 1957.

26) Matrone, G., R. Bunn and J. J. McHeile, J. Nutr., 84: 215-219. 1964. 


\title{
カゼインの第 4 胃内投与レベルがヤギにおける飼料中
}

\section{窒素および炭水化物の利用性に及ぼす影響}

\author{
藤原勉・田先威和夫* \\ 島根大学農学部，松江市 690 \\ *名古屋大学農学部, 名古屋市 464
}

第 4 胃内に投与したカゼインのレベルが，ヤギにおけ る空素抢よび炭水化物の利用性にいかなる影響を及惊す かを検討するため，第1胃および第4 胃にフィステルを 装着した去勢成雄ヤギ 3 頭を用いて実験し，次のような 結果を得た．1）蛋白質の見掛けの消化率は，カゼイン レベルが 10\%より20\%に増加するにつれて高くなる傾 向を示した，な技真の消化率はカぜインンベルにかかわ らず 96〜98\%となり，単胃動物のそれとほぼ等しいも のであった，また窒素の蓄積量注カゼインレべルの堌加 により増大した，2）蛋白質の生物価はカゼインレベル により変化することなく，その平均值は $57 \%$ あっった。 これはラットで得られた結果とょく一致した，3）窒素
出納の結果と血中窒素成分の濃度変化の様子から，血中 尿素態空素はカゼインレベルとともに增加し，かっその 增加率注体内窒素の蓄積量の増加率々此例していた，こ のことは血中尿素が飼料の第 1 胃内給与時と同様に，反 すう動物の蛋白筫代謝において咥秦のたくわえとして, 栄養的に意義のあることを示している４）血漿中総蛋 白浱唚はカゼインンベルの変動にほとんど影響を受け ず，先の值は一般的に考えられている範囲内にあった。 5）スターチの消化率は力がインレベルの堌加につれて 高くなる傾向定示した．また第 4 胃内に投与されたダル コースは注㜔全に吸收された。

日畜会報， $50(7) ： 471-478,1979$ 